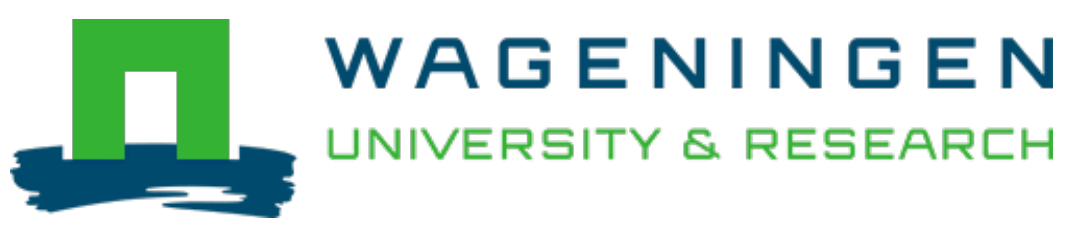

\author{
Demographic differentiation among pioneer tree species during secondary \\ succession of a Neotropical rainforest \\ Journal of Ecology \\ Martínez-Ramos, Miguel; Mar Gallego-Mahecha, María; Valverde, Teresa; Vega, Ernesto; Bongers, Frans \\ https://doi.org/10.1111/1365-2745.13738
}

This publication is made publicly available in the institutional repository of Wageningen University and Research, under the terms of article $25 \mathrm{fa}$ of the Dutch Copyright Act, also known as the Amendment Taverne. This has been done with explicit consent by the author.

Article 25 fa states that the author of a short scientific work funded either wholly or partially by Dutch public funds is entitled to make that work publicly available for no consideration following a reasonable period of time after the work was first published, provided that clear reference is made to the source of the first publication of the work.

This publication is distributed under The Association of Universities in the Netherlands (VSNU) 'Article $25 \mathrm{fa}$ implementation' project. In this project research outputs of researchers employed by Dutch Universities that comply with the legal requirements of Article $25 \mathrm{fa}$ of the Dutch Copyright Act are distributed online and free of cost or other barriers in institutional repositories. Research outputs are distributed six months after their first online publication in the original published version and with proper attribution to the source of the original publication.

You are permitted to download and use the publication for personal purposes. All rights remain with the author(s) and / or copyright owner(s) of this work. Any use of the publication or parts of it other than authorised under article $25 \mathrm{fa}$ of the Dutch Copyright act is prohibited. Wageningen University \& Research and the author(s) of this publication shall not be held responsible or liable for any damages resulting from your (re)use of this publication.

For questions regarding the public availability of this publication please contact openscience.library@wur.nl 


\title{
Demographic differentiation among pioneer tree species during secondary succession of a Neotropical rainforest
}

\author{
Miguel Martínez-Ramos ${ }^{1}$ (D) | María del Mar Gallego-Mahecha ${ }^{1}$ (D) | Teresa Valverde ${ }^{3}$ | \\ Ernesto Vega ${ }^{1}$ (D) | Frans Bongers ${ }^{2}$ (i)
}

${ }^{1}$ Instituto de Investigaciones en Ecosistemas y Sustentabilidad, Universidad Nacional Autónoma de México, Morelia, México

${ }^{2}$ Forest Ecology and Forest Management Group, Wageningen University \& Research, Wageningen, The Netherlands

${ }^{3}$ Departamento de Ecología y Recursos Naturales, Facultad de Ciencias, Universidad Nacional Autónoma de México, Ciudad de México, México

\section{Correspondence}

Miguel Martínez-Ramos

Email:mmartinez@cieco.unam.mx

Funding information

Consejo Nacional de Ciencia y Tecnología, Grant/Award Number: CB-2009-129740, CB-2012-179045 and CB-2015-255544; National Science Foundation, Grant/Award Number: DEB-147429; Dirección General de Asuntos del Personal Académico, Universidad Nacional Autónoma de México, Grant/Award Number: PAPIIT-IN21371, PAPIIT-IN211114, PAPIIT-IN211417 and PAPIIT-IN201020; Netherland Organisation for Scientific Research, Grant/Award Number: W85-326; Wageningen University $\&$ Research

Handling Editor: Chengjin Chu

\begin{abstract}
1. Early pioneer species share life histories enabling them to colonize disturbed sites, but how much they differ demographically and how such differentiation determines pioneer species turnover during succession are still open questions. Here, we approached these issues by comparing the demography of dominant pioneer tree species during the secondary succession of tropical rainforest in Southeast Mexico.
\end{abstract}

2. We assessed changes in population density, population structure, vital rates and intrinsic population growth rate $(r)$ of the pioneer species Trema micrantha, Cecropia peltata and Trichospermum mexicanum during the first 35 years of succession. For this, we combined chronosequence and long-term (from 2000 to 2018) data from 14 abandoned cornfields with 0.5-35 years fallow age.

3. Trema colonized and disappeared first during succession ( $<15$ years), followed by Cecropia (<28) and Trichospermum (>31). All species exhibited hump-shaped successional trajectories of population density and biomass with Trema reaching a peak first, followed by Cecropia and later Trichospermum. Species exhibited a fast reduction in $r$ with fallow age, with Trema reaching negative growth rates $(r<0)$ in the third, Cecropia in the fourth, and Trichospermum in the seventh year of succession. Recruitment, growth and mortality rates of seedlings and juveniles defined the period of population increase and the age of succession at which each species reached maximum density and biomass. The mortality rate in mature stages determined how long each species persisted during succession. An important variation in species replacement occurred among study sites. In some sites, one species was abundant and the others were almost absent, while it was the opposite in other sites. We inferred that priority inhibitory effects operated among species during the field colonization.

4. Synthesis. Although Trema, Cecropia and Trichospermum are considered typical pioneer trees, these species differed importantly in their demographic attributes during succession. The speed at which $r$ declined with age of succession indicated the moment at which each species reached its maximum density and species 
replacement sequence during succession. However, inter-specific priority inhibitory effects during field colonization may also be involved in the chance of colonization and replacement between species with similar regeneration strategies.

\section{KEYWORDS}

life-history strategies, niche differentiation, population dynamics, priority effects, Selva Lacandona, species replacement

\section{1 | INTRODUCTION}

More than four decades ago, it was recognized that we are living in the era of secondary vegetation (Gómez-Pompa et al., 1972). Today, old-growth forests cover smaller areas than second-growth forests (sensu Chazdon, 2014) in most regions on Earth (Brown \& Lugo, 1990; Turubanova et al., 2018). Deforestation, land-use change towards agriculture, field abandonment and ecological succession are the main forces driving this on-going transformation (Aide et al., 2013; Hansen et al., 2013). In this context, second-growth forests are becoming keystones for the conservation of biodiversity, ecosystem functioning and services (Chazdon et al., 2016; Poorter et al., 2016; Rozendaal et al., 2019). Therefore, there is an urgent need to understand ecological processes and mechanisms determining natural regeneration and successional dynamics of second-growth forests, especially in abandoned agricultural fields (Chazdon, 2014). Regenerating second-growth forests is an important task for ecological restoration of degraded lands in human-modified landscapes (Brancalion \& van Mellis, 2017).

Secondary succession can be understood as a turnover process among species differing in life-history and functional traits, which is initiated by a disturbance (Halpern, 1989; Huston \& Smith, 1987). Such differences determine the species' ability to survive, grow and reproduce in an environment that changes dynamically in abiotic conditions, resources and biotic interactions (Arroyo-Rodríguez et al., 2017; Horn, 1974; Martínez-Ramos, 1985). This changing environment affects the species' population dynamics and this, in turn, results in species replacement through time (van Breugel et al., 2006).

Often, life-history strategies of tropical rainforest tree species are dichotomously categorized into pioneers and non-pioneers (Swaine \& Whitmore, 1988). Pioneer species (or light-demanding) are considered short-lived, with early maturation, fast growth and high reproductive rates, which establish only in open areas. Non-pioneer species (or shade-tolerant) are long-lived, with late maturation, slow growth and low reproductive rates, which establish under shade conditions. Although this classification is useful to assess community changes along succession (Finegan, 1984) it is based on general (average) demographic patterns and underestimates the high demographic variability found among tropical tree species (MartínezRamos et al., 1989; Poorter et al., 2008). Pioneer and non-pioneer species represent the ends of a wide spectrum of life histories and regeneration strategies (Hubbell, 2005; Martínez-Ramos, 1985). The demographic exploration of such variability is core for understanding processes of natural regeneration and old-field forest succession.

Community-oriented studies have shown that old-field succession in the tropics is not an easily predictable process (Norden et al., 2015). Replacement not necessarily occurs among tree species with contrasting life histories (e.g. non-pioneer replacing pioneer species), but also among species with similar life histories (e.g. pioneer replacing pioneer species; van Breugel et al., 2007; Brokaw, 1987; Mesquita et al., 2015). Inhibitory and facilitation priority effects (order and timing of species arrival), and the way niche partitioning occurs among species, influence plant community assembly in succession (Connell \& Slatyer, 1977; Fukami, 2015). Arrested succession by the colonization of bracken fern in degraded fields (Suazo-Ortuño et al., 2015) exemplifies inhibitory priority effects, while rapid forest recovery, after the colonization of the pioneer tree Cecropia insignis in clear-cuts (Mesquita et al., 2015), exemplifies facilitation priority effects. Detailed demographic analysis of the species can help to explore such priority effects and partitioning processes (Finegan, 1984; Metcalf et al., 2009; Silvertown \& Franco, 1993). However, most demographic studies in successional systems have focused on species that dominate at different moments of succession (Marcante et al., 2009; Martínez-Ramos et al., 1989; Primack \& Lee, 1991), or on changes in vital rates of a single species during succession (Otárola \& Avalos, 2014; Pascarella et al., 2007; Valverde \& Silvertown, 1998). Comparative studies of the demographic behaviour of different pioneer tree species during succession are scarce (Brokaw, 1987; Pearson et al., 2003; Santos et al., 2012). Thus, the question of how pioneer species replace each other during the first stages of old-field succession is still open.

This study explored demographic mechanisms underlying the replacement of pioneer tree species during the first stages of the old-field succession in a tropical rainforest. We used three pioneer species (Trema micrantha, Cannabaceae; Cecropia peltata, Urticaceae; and Trichospermum mexicanum, Malvaceae), which are dominant during the first 30 years of old-field forest succession in the tropical forests of Southern Mexico (van Breugel et al., 2007) to test how demographic differences among pioneer species explain their position during succession. Although these species belong to different plant families, they have similar regeneration strategies and functional traits (Tables S1 and S2). Specifically, we addressed the following questions: (a) to what extent do population density, population structure, average size-specific and fallow age-specific vital rates (survival, growth, reproduction), and 
population growth rates differ between pioneer species during the first three decades of the successional process? (b) Do these demographic differences explain the replacement order among pioneer species during succession? Generally, first colonizing pioneer species are extreme light demanding, showing high recruitment, growth and mortality rates. Species replacing them would be less light demanding, with lower vital rates. Therefore, we predict a sequence of species replacement going from the one having the highest vital rates to the species with the lowest rates. This prediction, however, can be weakened if species behave differently depending on site and year-related variability in environmental conditions and on propagule availability at the moment of field abandonment (Chazdon, 2014). Thus, distinguishing demographic differences among pioneer species is critical for understanding the predictable/stochastic nature of successional processes. Also, such an approach is useful for providing guidelines for ecological restoration, as discussed in the concluding remarks.

\section{2 | MATERIALS AND METHODS}

\section{1 | Study site}

The study was conducted in the Marqués de Comillas region, southeast Mexico $\left(16^{\circ} 04^{\prime} \mathrm{N}, 90^{\circ} 45^{\prime} \mathrm{W}\right)$. The average annual rainfall is about $3,000 \mathrm{~mm}$, with a dry season from January to April $(<60 \mathrm{~mm}$ per month), and mean monthly temperature about $22^{\circ} \mathrm{C}$ (MartínezRamos et al., 2009). The dominant vegetation is a lowland tropical rainforest with a structure and composition that change across different geomorphological units (Navarrete-Segueda et al., 2017). Presently, nearly $30 \%$ of the region is covered by second-growth forests of different ages, which have resulted from the abandonment of crop and pasture fields (Carabias et al., 2015; Martínez-Ramos et al., 2016).

The study species are typical pioneer trees from the Neotropics. Trema micrantha (hereafter Trema) reaches up to $20 \mathrm{~m}$ in height, produces fleshy fruits eaten by birds (Pennington \& Sarukhán, 2005), and is a highly light-demanding tree that requires large open sites to grow and regenerate (Dalling et al., 2004). Cecropia peltata (hereafter Cecropia) reaches up to $30 \mathrm{~m}$ height, produces fleshy fruits along the year, each one with thousands of small seeds dispersed by several frugivores (Estrada et al., 2010). Cecropia may regenerate in forest gaps smaller than those needed for Trema (Brokaw, 1987). Trichospermum mexicanum (hereafter Trichospermum) grows abundantly in secondary vegetation, reaching up to $20 \mathrm{~m}$ height (Pennington \& Sarukhán, 2005), produce winddispersed seeds during a short dry season (Rodríguez-Velázquez et al., 2009). Long-lived seeds in the soil could compensate such dispersal limitation, unlike Cecropia soil seeds that are short-lived (Álvarez-Buylla \& Martínez-Ramos, 1990). The lower net assimilation rates and lower leaf nitrogen content of Trichospermum than Cecropia (Bongers \& Popma, 1990; Sanchez et al., 2009) suggest the first species is relatively less light demanding than the second one. Other life-history and functional traits of the studied species are shown in Tables S1 and S2.

\section{2 | Study system}

In 2000 , we established one permanent plot $(10 \times 50 \mathrm{~m})$ in each one of 11 old-fields, which differed in fallow age (range: 1.5-17 years; Table S3). Some plots were lost due to escaped fires from adjacent crop fields, which forced us to establish one new plot in 2002 ( 1.5 years fallow age) and two in 2004 ( 0.5 years fallow age). Thus, in total, we had data from 14 plots (Table S3). Due to the land-use dynamics in the region, the number of plots was unbalanced regarding fallow age. Nonetheless, the fallow age range (0.5-17 years) of the plots represented the most common secondary forest ages in the region. Although all fields were cornfields, some of them differed in their land-use histories (Table S3).

We used data from most study plots and census years to assess how demographic variables changed through succession. However, for demographic rates of the earlier life cycle stages (seed, seedling, juvenile), we used a subset of plots designed for that purpose.

\subsubsection{Seed bank}

To estimate seed density in the soil we used five plots: R-1 had 1.5, $\mathrm{H}-1$ three years, $\mathrm{F}-4$ six years, $\mathrm{H}-10$ twelve years and $\mathrm{H}-17$ nineteen years fallow-age at the moment we started sampling the seed bank (October 2002). In each plot, twenty soil samples were randomly collected with a metallic cylindrical core of $10 \mathrm{~cm}$ in diameter $\times 10 \mathrm{~cm}$ in depth, representing a sampling area of 0.157 $\mathrm{m}^{2}$ per plot. Sampling was conducted on two dates (one in the dry season and another in the rainy season) for two and half consecutive years (from 2002 to 2004; five sampling dates in total). Each soil sample was spread in individual trays with sterile soil, which were put on tables inside a rustic shade-house covered with a transparent plastic mesh to avoid contamination with external seeds, which allowed a high light level for the germination of these light-demanding seeds. The number of emerged seedlings of the three studied species was recorded daily during c. 3 months until no more seedlings emerged. Data from the 20 soil samples per plot were combined to have seed bank density values (seeds $0.16 \mathrm{~m}^{-2}$ ) per species, plot and sampling date.

\subsubsection{Newly dispersed seeds (seed rain)}

To record the seed rain, we used the same plots as for the seed bank sampling. Twelve conical traps ( $0.5 \mathrm{~m}$ in radius and $0.5 \mathrm{~m}$ deep, each) were established randomly in each plot. Three poles $1 \mathrm{~m}$ above the ground sustained each trap. During the same years (2002-2004) used for the seed bank sampling, litter was collected from each trap every 2 weeks for 3 years. In the laboratory, samples were sorted to 
separate and count the seeds per species with the help of a magnifying glass. Data from the 24 samples collected per plot per year were combined to have values of seed rain density (seeds $9.42 \mathrm{~m}^{-2}$ ) per species, plot and sampling year.

\subsection{3 | Seedlings and small juveniles}

In the same five plots used to sample seed bank and seed rain, we established 12 sub-plots of $1 \times 2 \mathrm{~m}$ each (a total of 60 subplots) where all seedlings ( 5 to $50 \mathrm{~cm}$ height) and small juveniles (51 to $149 \mathrm{~cm}$ height) of the three studied species were recorded and tagged. At intervals of about 3-4 months, every year from August 2001 to December 2014, we recorded the number of surviving individuals and newly emerged seedlings measuring their height. For the purposes of this study, only data from annual censuses were used.

\subsection{4 | Large juveniles and mature individuals}

For individuals with heights $\geq 150 \mathrm{~cm}$, we conducted annual censuses from 2000 to 2018 in the total area of each of our 14 study plots. All individuals of each species were recorded, tagged with an ID number, and their diameter at breast height $(\mathrm{DBH})$ measured. At each census, we recorded the $\mathrm{DBH}$ of surviving trees and of new recruits (i.e. individuals reaching $1.5 \mathrm{~m}$ in height).

\subsection{5 | Reproductive schedule}

In July 2017, we selected 24 potentially reproductive individuals (6-40 cm DBH) of Cecropia and 35 of Trichospermum to estimate size-specific fecundity rates (seeds produced per tree, per year). These individuals were located outside the plots, in patches of second-growth forest and along trails as very few were found in the study plots. From July 2017 to July 2018, we recorded monthly the reproductive status (with or without fruits) of each individual. We estimated the number of seeds produced per tree during 1 year, following the protocol described in the Supporting information (Appendix S4). For Trema, we did not estimate fecundity because we did not find enough mature individuals, either within or nearby the plots.

\section{3 | Data analysis}

\subsection{1 | Changes in population density and biomass during succession}

To document successional trajectories of change in population density and biomass of the species, we combined chronosequence and repeated-measures data (Norden et al., 2015). First, for each individual, we estimated above-ground biomass (kg dry matter) using the equation $\ln$ (biomass) $=-1.13+2.27 \ln (\mathrm{DBH})+1.9 \ln (\mathrm{WSG})$, where $\mathrm{DBH}$ is the stem diameter at breast height of a tree and WSG $\left(\mathrm{g} / \mathrm{cm}^{3}\right)$ is the mean wood-specific gravity of the tree's species (Van Breugel et al., 2011). Data of WSG for our species were obtained from Lohbeck et al. (2015). Then, the 14 study plots were ordered according to their initial fallow age, from the youngest to the oldest (Table S3). For each plot, we had between two and 19 consecutive annual censuses. Adding census years to the initial fallow age of each plot, a wide range of successional ages, from 1 to 35 years, was covered (Figure S1).

To test differences among species in trajectories of change in population density and biomass (biomass of all individuals per species and plot) during succession, we considered individuals $\geq 140 \mathrm{~cm}$ height recorded in all censuses and plots $<15$ years fallow age. This cut-off was established to include only fallow ages for which density and biomass data were available for the three species. We used Linear Mixed Effect Models (LMEM) to test the effects of species (a factor of three levels), fallow age a regressor, and the species $\times$ fallow age interaction on density or biomass. Response variables were log-transformed to meet normality criteria. The plot, census year or sampling date (hereafter 'year') was included as random variables. In this and following analyses, we assumed that the plot random effects were related to priority effects due to site conditions, and the year random effects to the temporal environmental variation affecting species population dynamics.

\subsubsection{Changes in population structure and tree size during succession}

Individuals of each species were assigned to one of the following stage categories: newly dispersed seeds (seed rain), seeds in the soil (seed bank), regenerative individuals [including seedlings and small juveniles ( $<150 \mathrm{~cm}$ height)], trees $\leq 150 \mathrm{~cm}$ height and $<2 \mathrm{~cm} \mathrm{DBH}$, 2.1-4 cm DBH, 4.1-8 cm DBH, 8.1-16 cm DBH and $>16 \mathrm{~cm} \mathrm{DBH}$. Seed rain and seed bank were analysed separately from the other size categories as described below.

We used LMEM to test differences in seed rain and seed bank among species during succession. The logarithm of the seed rain density or seed bank density were response variables, species a factor (three levels), fallow age a regressor. Plot and sampling year were included as random variables.

For seedling and later stage categories, we scaled the density values to a standard area of 1 ha. Then, for plots with the same fallow age, we summed the number of individuals per category, and the population structure of each species at each fallow age was described as the proportion of individuals in the different categories. We used a generalized linear model (GLM) to test whether the frequency of individuals varied depending on the interaction among species (a factor with three levels), stage category (a factor with six levels) and fallow age (a factor of 14 levels, corresponding to the years with data for the three species). A significant interaction 
between these factors indicates that the population structure of the species varied differently during succession. A negative binomial error was used to overcome overdispersion.

To test differences among species in tree size change during succession, we analysed fallow age- $\mathrm{DBH}$ and age-biomass relationships. For this, we used DBH and biomass records for all individuals with a height $\geq 150 \mathrm{~cm}$ of each species obtained across all plots and years. Then, we conducted LMEM to test the effects of species, fallow age (a continuous variable) and species $\times$ fallow age interaction on $\mathrm{DBH}$. Plot, year and individual were included as random variables.

\subsection{3 | Average species size-specific vital rates}

Size-specific vital rates were estimated for each species (individuals with a height $\geq 150 \mathrm{~cm}$ ). For survival, we used $\mathrm{DBH}$ records of all surviving or dying individuals from 1 year to the next, across all plots and years. A Generalized Linear Mixed Effect Model (GLMEM) was used to test the effects of species, DBH (a regressor), and the species $\times \mathrm{DBH}$ interaction on individual condition (live $=1$, dead $=0$ ). Plot and census year were included as random variables, and a binomial error and a logit link function were set in the model. The same procedure was applied to compare sizespecific growth rates among species. We calculated the relative growth rate (RGR) of each surviving individual as $\left[\log \left(\mathrm{DBH}_{1}\right)\right.$ - $\log$ $\left.\left(\mathrm{DBH}_{0}\right)\right] / \mathrm{t}$, where $\mathrm{DBH}_{0}$ is $\mathrm{DBH}$ at the beginning of an annual interval, $\mathrm{DBH}_{1}$ is $\mathrm{DBH}$ at the end of that interval, and $\mathrm{t}$ is a 1-year interval. A normal error distribution and an identity link function were used in the LMEM analysis. To deal with the heteroscedasticity of RGR along the $\mathrm{DBH}$ range, a weighted variance factor was considered (Pinheiro et al., 2020). For size-specific annual fecundity, we used maximum seed production records of individuals of Cecropia and Trichospermum monitored during the year (see above) as an estimator of fecundity. We used a GLM to test differences in fecundity rates between species, considering a log-link function and a negative binomial error to overcome overdispersion (Anderson, 2008).

\subsection{4 | Changes of vital rates and population growth rate during succession}

Fallow age-specific recruitment (i.e. the number of individuals entering in a given life stage), mortality and progression (transition from one to further life stage) rates were estimated for five size categories: seedling (individuals $\leq 50-\mathrm{cm}$ height), juvenile-1 (51-149 cm height), juvenile-2 (150 cm height and DBH $<1 \mathrm{~cm})$, premature ( $\geq 1$ to $4.9 \mathrm{~cm} \mathrm{DBH}$ ) and mature ( $\geq 5 \mathrm{~cm} \mathrm{DBH}$ ). The minimum size of $5-\mathrm{cm} \mathrm{DBH}$ for mature trees was established based on field observations on the smallest reproductive trees. Vital rates were estimated for the 1, 2, 3 and 4 more years of succession. We established these categories as the seedlings and juvenile-1 individuals of all species were restricted to fallow ages less than 5 years, and because Trema had very few premature and mature individuals in later ages. We used LMEM (for log-transformed count data) or GLMEM (binary variables), to test the effect of species, fallow age (a factor with four levels) and the species $\times$ fallow age interaction on vital rates within each size category, including plot and year as random variables.

We estimated intrinsic population growth rates per species, plots and years as $r_{i, j}=\left[\left(\operatorname{Ln}\left(N_{t+1}\right)-\operatorname{Ln}\left(N_{t}\right)\right] /(M)\right.$. Here, $r_{i, j}$ is the intrinsic population growth rate of a species in the plot $i$ and year $j, N_{t}$ is population density (individuals $>150 \mathrm{~cm}$ in height) at the start of a given census year, $N_{t+1}$ is the population at the end of the year, and $M$ is the number of months passed between census. Values of $r$ (ind ind ${ }^{-1} \mathrm{mo}^{-1}$ ) $>0$ indicate growing populations, $r<0$ to declining populations, and $r=0$ to populations in numeric equilibrium. We used data from every plot and year with an initial population of 10 or more individuals per species. We calculated $r$ year by year until just one individual remained in the plot. We used LMEM to test effects of species, fallow age as a regressor, and the species $\times$ fallow age interaction on $r$, including plot and year as random variables.

The LMEM, GLMEM and GLM analyses were performed in $R(R$ Core \& Team, 2020) as described elsewhere (Anderson, 2008; Bates et al., 2015; Pinheiro et al., 2020).

\section{3 | RESULTS}

Overall, we analysed 25 demographic variables. Trema and Cecropia differed significantly in 18 (75\%), Trema and Trichospermum in 21 (88\%), and Cecropia and Trichospermum in 18 (Table S4).

\section{1 | Successional changes in population density and biomass}

Across plots and fallow ages, considering trees $\geq 1 \mathrm{~cm} \mathrm{DBH}$, Trema had the lowest mean $( \pm S E)$ population density and biomass ( $74 \pm 34 \mathrm{ind} / \mathrm{ha}, 4.9 \pm 34.0 \mathrm{Mg}$ ), Trichospermum the highest $(1,698 \pm 207,141.3 \pm 207.4)$ and Cecropia the intermediate ones $(430 \pm 145,26.9 \pm 145.3)$. On average, all species showed hump-shaped successional trajectories of change in population density and biomass (Figure 1a,b). Trema exhibited a peak earlier than Cecropia and Cecropia earlier than Trichospermum. All these changes were significant (Table S5), and although this replacement sequence was repeated in several plots, the trajectories were erratic. In fact, important random effects of plot, but not of year, were detected (Table S5). Such random effects resulted from a strong inter-plot variation in the successional trajectories (Figure 1a,b). Interestingly, in plots where Trema had a high initial population density, Cecropia showed a low one (e.g. plot R-0), and vice versa (e.g. R-1, H-1 and P-2; Figure S4). Considering the older surviving individuals in the 
(a)
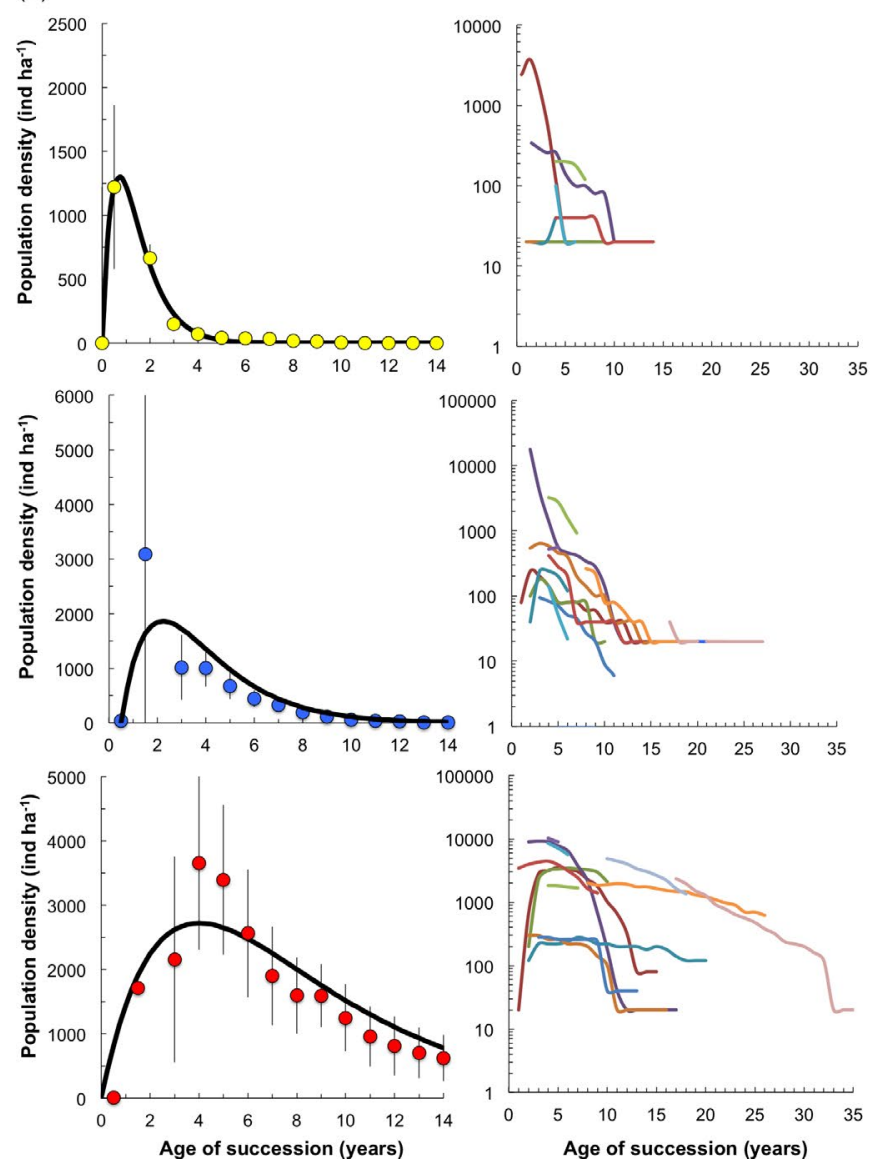

10000
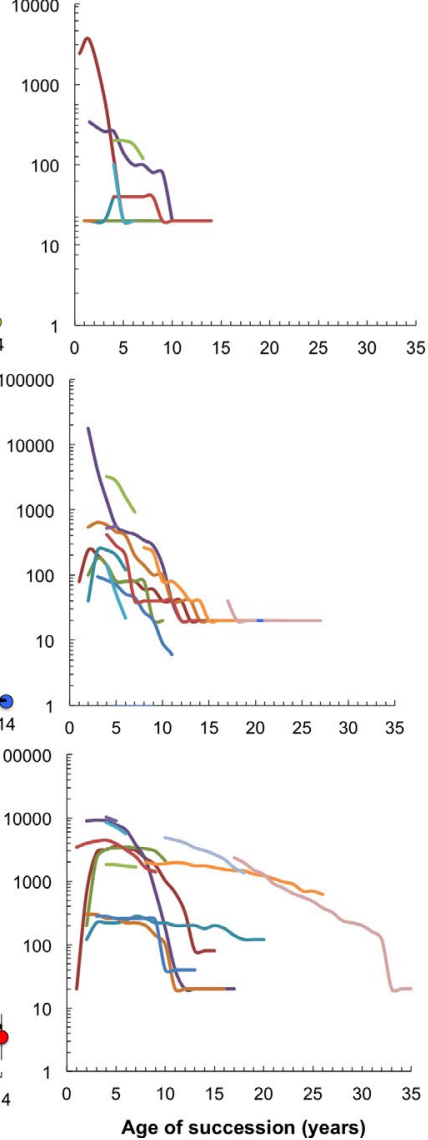

(b)
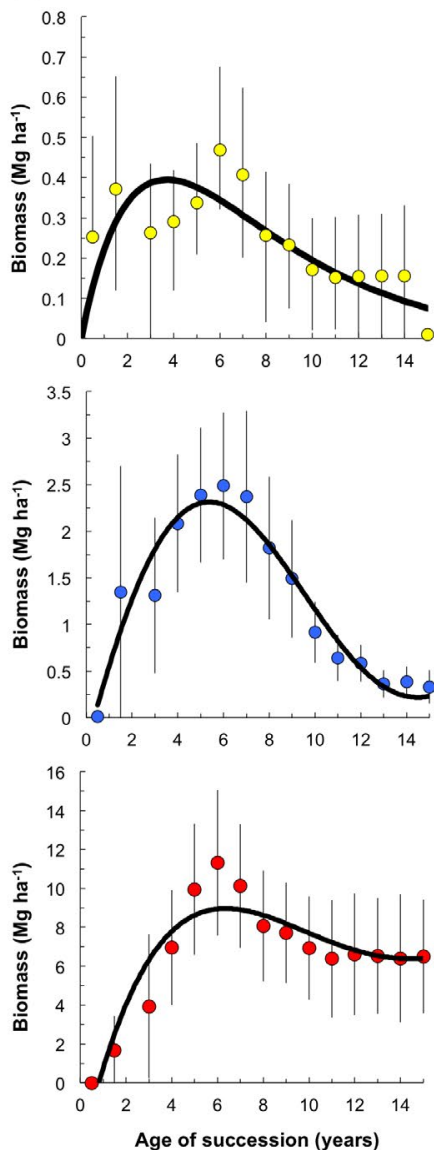
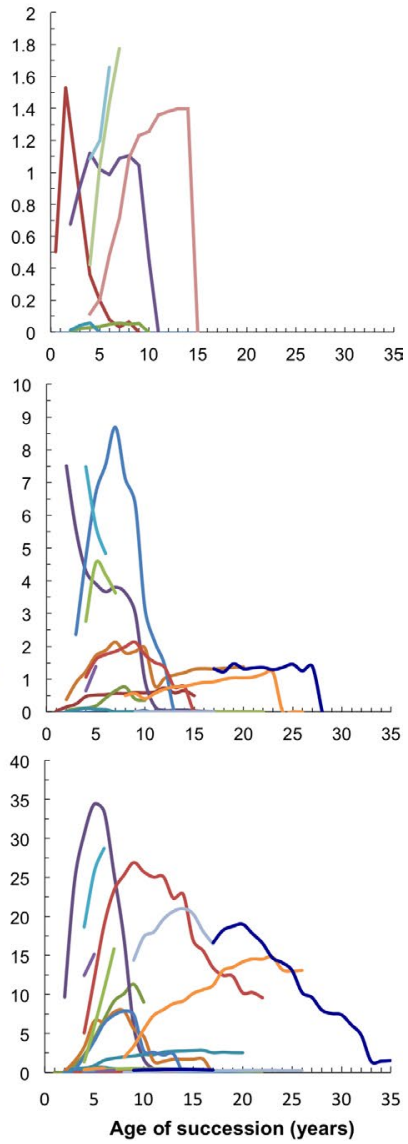

FIGURE 1 Average and inter-plot variation of successional trajectories of change in population density [panel (a)] and population biomass [panel (b)] of Trema (yellow), Cecropia (blue) and Trichospermum (red) during the first three decades of old-field succession in Marqués de Comillas, Southern Mexico. In the left graphs of the panels, the points represent mean values for plots sharing the same fallow age (Age, vertical lines one standard error). The continuous black curves correspond to the best fitted nonlinear models to the mean values; for AGB trajectories of Cecropia and Trichospermum polynomial models (of order 5 and 4, respectively) were adjusted, while for the other trajectories the model $y=a \times A g e \times \exp (-b \times A g e)$, where $y$ is the population density of a given species or the AGB of Trema, was adjusted. In the left graphs of the panels, individual-plot successional trajectories are shown. Note that the scale in the $y$-axis varies among species

plots, it can be noted that Trema disappeared after 15 years of succession, Cecropia after 27 years, and Trichospermum after 35 years (Figure 1 ).

\subsection{Changes in population structure and tree size during succession}

Species differed in seed rain and seed bank densities during succession (Table S6). In Trema, seed rain was very high at the beginning of succession and then declined rapidly, while the seed bank varied independently of fallow age, and was proportionately much higher than the seed rain in most fallow ages (Figure 2; Figure S5). In contrast, seed rain of Cecropia and Trichospermum exhibited humpshaped successional trajectories, and in both species, the seed bank increased with fallow age (Figure 2). However, while the seed rain of Cecropia was proportionally more abundant than the seed bank along succession, the opposite was true for Trichospermum
(Figure S5). In these analyses, the random effects of the year were higher than those of plot (Table S6).

Considering stages later than seeds, population structure of the species changed differently during succession (significant species $\times$ stage $\times$ fallow age interaction; $\chi^{2}=4,751, d f=140, p<0.001$ ). The population structure of Trema changed rapidly during the first 10 years of succession, from being dominated by seedlings and juveniles to a population composed only by large trees $(\mathrm{DBH} \geq 16 \mathrm{~cm}$; Figure S6). This change took 20 years in Cecropia and more than 30 years in Trichospermum (Figure S6). Only Trichospermum still had small individuals ( $<150 \mathrm{~cm}$ height) after 10 years of succession.

Tree size increased linearly with fallow age at different rates among species (Table S7a,b). Trema exhibited the highest rate increase in $\mathrm{DBH}$ and biomass, Cecropia showed an intermediate rate, and Trichospermum the lowest one (Figure 3; Figure S7). Within each species, there was large size variability among individual trees within the same fallow ages, mostly due to the individual and plot random effects (Table S7a,b). Maximum DBH in Trema was $22.8 \mathrm{~cm}(76.3 \mathrm{~kg}$ 

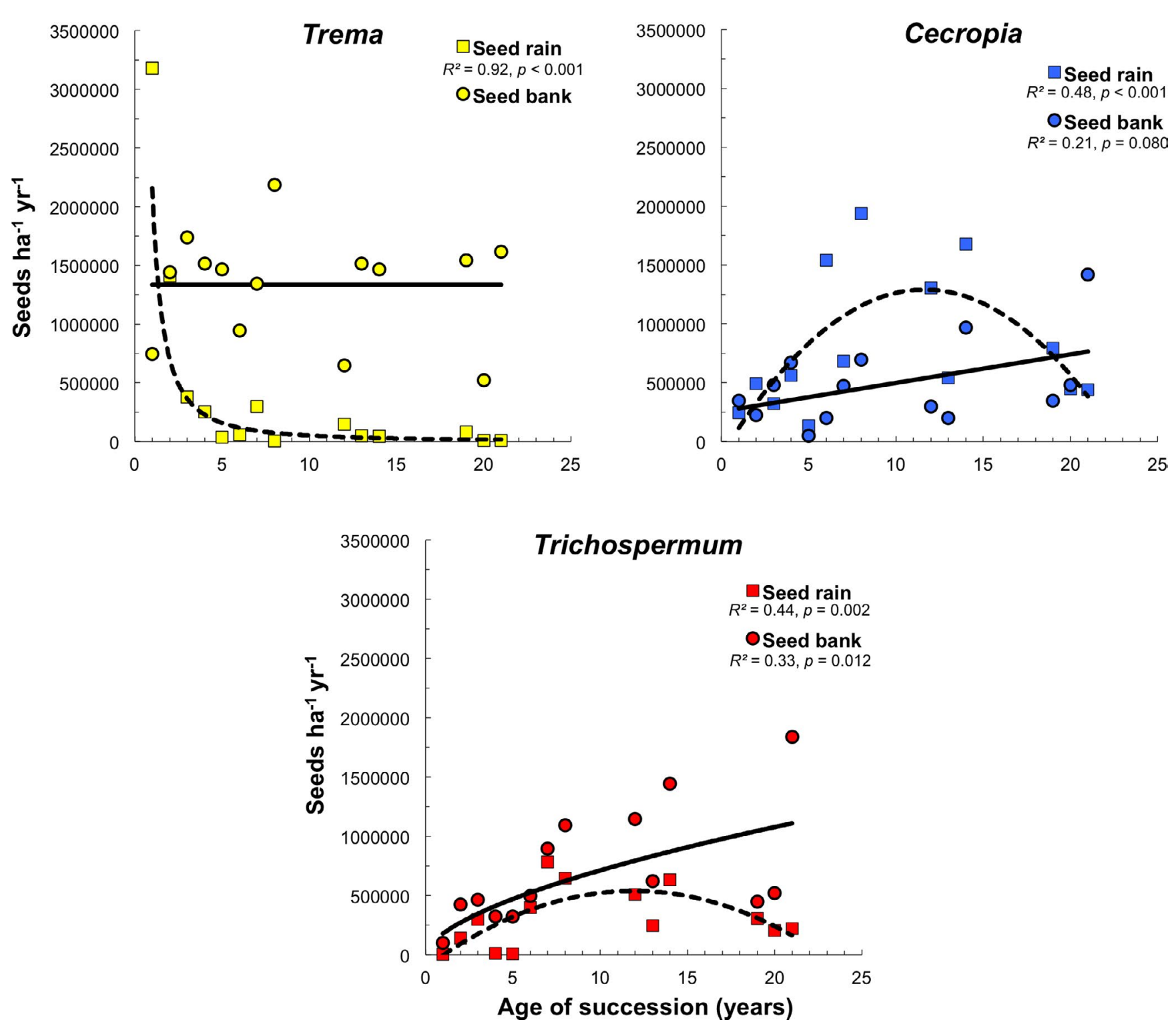

FIGURE 2 Changes in the seed rain and seed bank densities of Trema, Cecropia and Trichospermum as a function of age of succession (Age) in abandoned cornfields of Marqués de Comillas, Southern Mexico. For the seed bank, values are an average of two data (seasons) taken per year per site. In the graph legends, below the dependent variable names, the proportion of variance $\left(R^{2}\right)$ and associated $p$ values for the best-fitted regression adjusted models for seed rain (SR, dotted lines) and seed bank (SB, continuous lines) are shown. Models for seed rain: Trema $\left[S R=\exp (15.00-1.66 \times \ln (\right.$ Age $)]$, Cecropia $\left[S R=\exp \left(12.187+0.335 \times\right.\right.$ Age $-0.014 \times$ Age $\left.\left.^{2}\right)\right]$, Trichospermum $\left[S R=\exp \left(10.936+0.392 \times A g e-0.016 \times A g e^{2}\right)\right]$; models for seed bank: Trema (not significant, the solid line corresponds to the mean value across ages), Cecropia $[S B=\exp (12.611+0.045 \times A g e)]$, Trichospermum $[S B=\exp (12.611+0.045 \times A g e)]$. All models were adjusted with GLM routines, considering a quasipoisson error and a log-link function

biomass), $23.5 \mathrm{~cm}(81.2 \mathrm{~kg})$ in Cecropia, and $34.9 \mathrm{~cm}(187 \mathrm{~kg})$ in Trichospermum.

\section{3 | Interspecific differences in size-specific vital rates}

Survival rate was affected by species, $\mathrm{DBH}$ and the species $\times \mathrm{DBH}$ interaction (Table S8a). Trema had a significantly smaller survival rate for trees $<15 \mathrm{~cm}$ DBH than Cecropia and this than Trichospermum (Figure 4). Random effects were small and similar for plot and year.
RGR differed among species, decreased with $\mathrm{DBH}$, and was affected by the species $\times \mathrm{DBH}$ interaction. Plot and year random effects were negligible (Table S8b,c). Trema had significantly higher RGR in small individuals than those of the other species. Also, Trema exhibited a faster RGR decline with DBH than Cecropia and this than Trichospermum (Figure 4; Table S8b,c).

The fecundity rate increased exponentially with $\mathrm{DBH}$ and was affected by the species $\times \mathrm{DBH}$ interaction (Table S8d). The fecundity rate of Cecropia was about 10 times higher than that of Trichospermum for trees with $5 \mathrm{~cm} \mathrm{DBH}$, and three times higher for trees $30 \mathrm{~cm}$ DBH (Figure 4). 

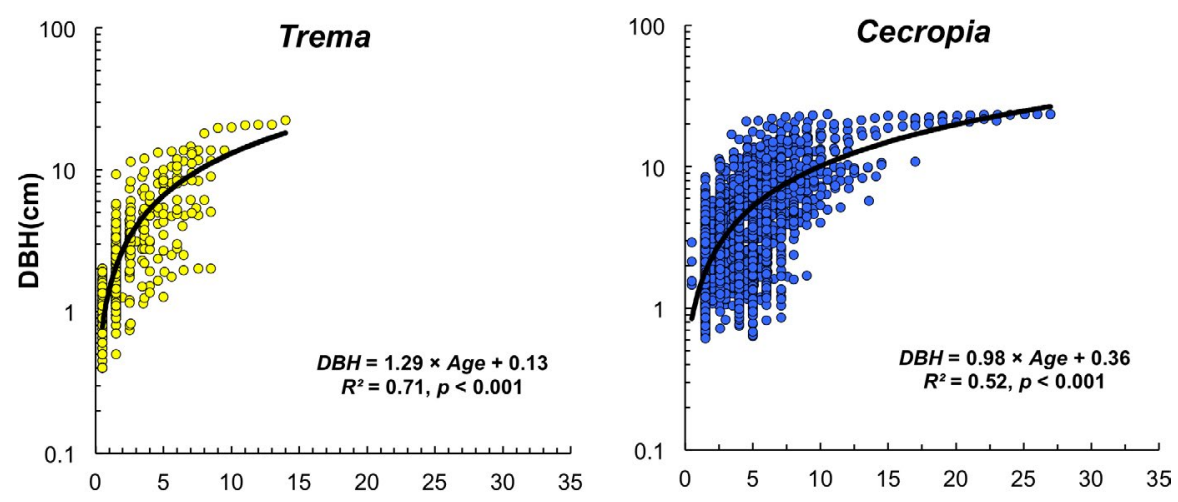

FIGURE 3 Successional changes in tree diameter at breast height (DBH) for Trema, Cecropia and Trichospermum in abandoned cornfields of Marqués de Comillas, Southern Mexico. Each dot represents an individual and the black line the best fitted linear regression model (parameters and statistics inside each graph)

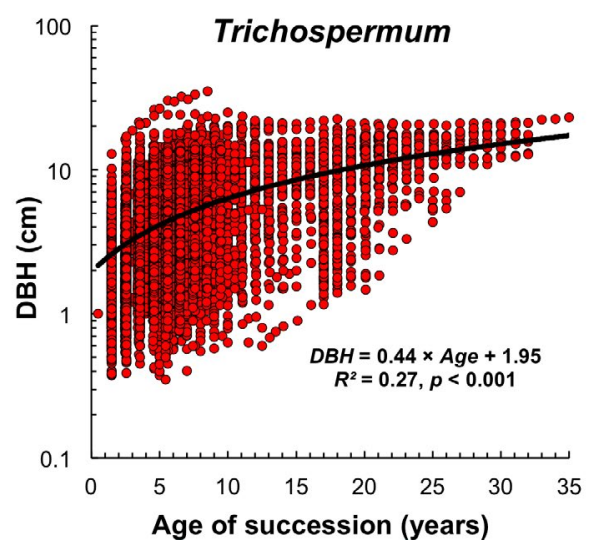

\subsection{Changes in stage-specific vital rates and population growth rate during succession}

In most cases, stage-specific vital rates differed among ages of succession, among species, and in several cases with the species $\times$ age interaction (Tables S9-S11). Generally, random effects due to plot were higher than those of year. Recruitment of seedlings decreased with the age of succession, independently of species (Table S9a). However, while in Trema it was restricted to the first 2 years of succession, in Cecropia recruitment of seedlings continued until the third, and in Trichospermum until the fourth year (Figure 5a). Recruitment of juvenile-1 individuals also declined with age of succession in all species (Table S9b; Figure 5a). Recruitment of juvenile2 and premature individuals of Trema declined with fallow age while the opposite occurred in Trichospermum, Cecropia showing an intermediate behaviour (significant species $\times$ age interaction in both stages; Table S9c,d; Figure 5a). Recruitment of mature individuals was higher in Trichospermum and Cecropia than in Trema independently of fallow age (Table S9e; Figure $5 a$ ).

From seedling to juvenile-2, at every fallow age, the mortality rate was significantly higher in Trema and Cecropia than in Trichospermum (Table S10a,d; Figure 5b). In the premature and mature stages, Trema suffered a higher mortality rate than Cecropia and this than Trichospermum after 3 years of succession (Table S10f-h). The progression rate in the seedling and juvenile-1 stages was lower in Trema and Cecropia than in Trichospermum (Table S11a,b; Figure 5c). In the juvenile-2 stage, the progression rate declined with fallow age in Trema, in Cecropia increased,

while in Trichospermum was maximum after 3 years of succession (significant species $\times$ fallow age interaction Table S11c,d). In the premature stage, the progression rate in Trema increased with fallow age while the opposite occurred in Cecropia and Trichospermum (Table S11e,f; Figure 5c). In all these analyses, random effects of plot and year were frequently null or higher for plot (Tables S9-S11).

The intrinsic population growth rate $(r)$ varied among species, decreased in a concave way with increasing fallow age, and was affected by the species $\times$ fallow age interaction (Table S12; Figure $5 d-$ f). No random effects of plot or year were detected. On average, Trema had the lowest $r\left(-0.079 \pm 0.043\right.$ ind ind $\left.{ }^{-1} \mathrm{mo}^{-1}\right)$, Cecropia the intermediate $(-0.015 \pm 0.019)$, and Trichospermum the highest one $(0.034 \pm 0.018)$. Trema exhibited the highest initial $r$ and the strongest reduction in this rate with increasing fallow age, compared to Cecropia and Trichospermum (Table S12; Figure 5d,e,f).

\section{4 | DISCUSSION}

Although the studied species are classified as early pioneer trees they differed significantly in most demographic attributes analysed (Table S1). Trema was the first colonizer and persisted for a lower number of years during succession ( $<14$ years), followed by Cecropia ( $<28$ years), and Trichospermum ( $>30$ years). However, the population dynamics of these species occurred with a high spatial and temporal variability, which made the sequence of species replacement in a particular site unpredictable. 
Trema
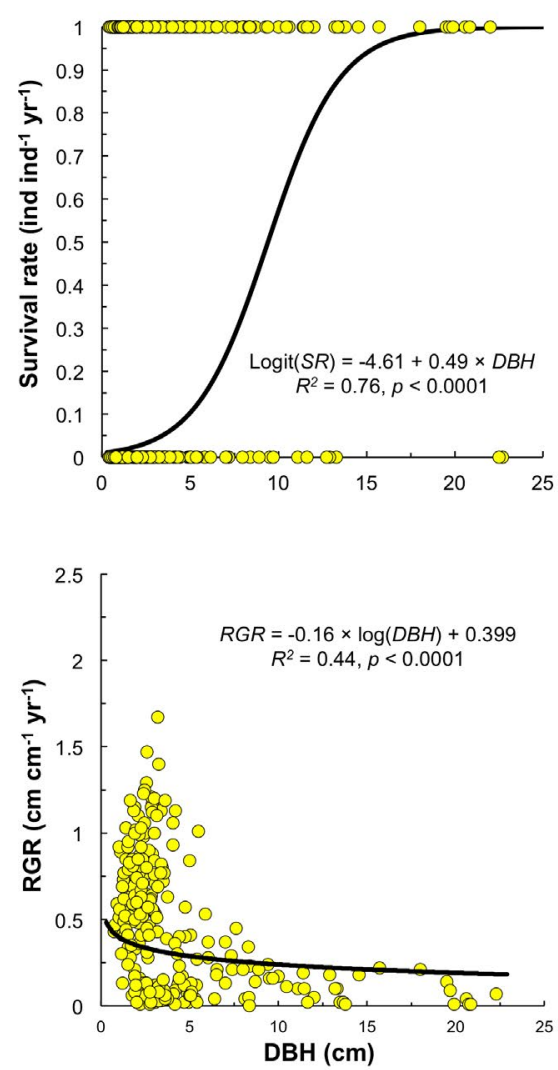

Cecropia
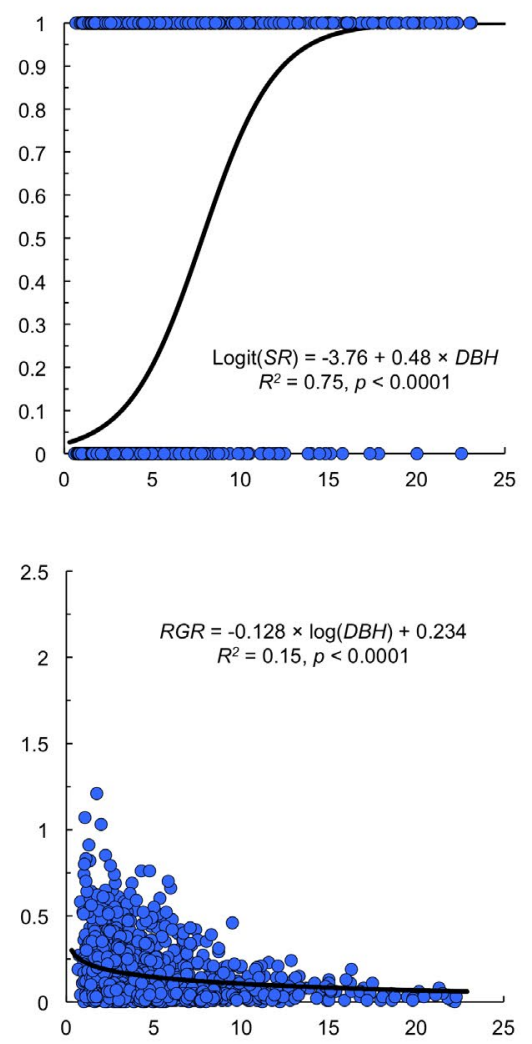

Trichospermum
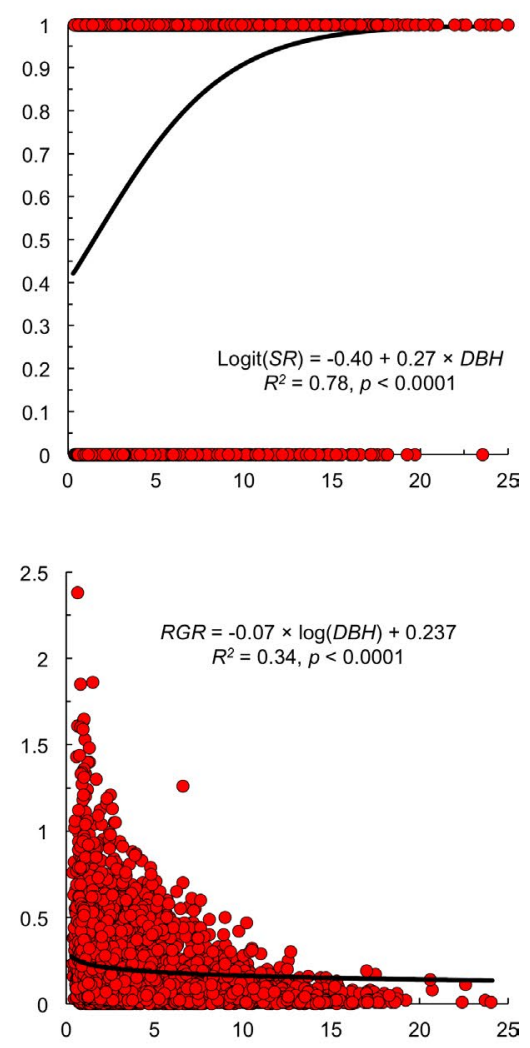
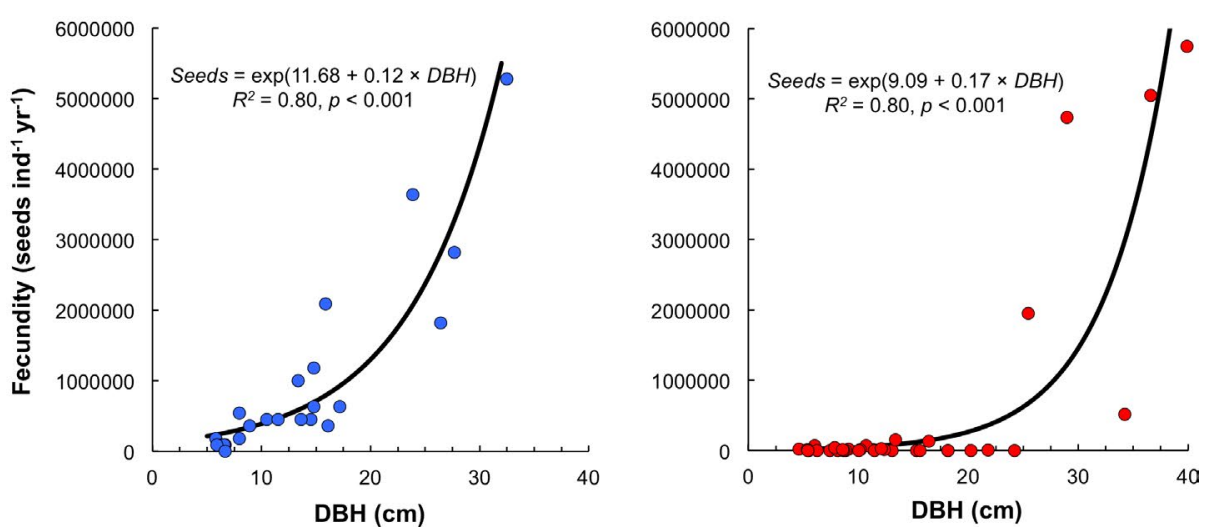

FIGURE 4 Size-specific curves of survival, growth and fecundity rates for Trema, Cecropia and Trichospermum in Marqués de Comillas, Southern Mexico. Graphs corresponding to each species are organised vertically. Insets are the GLMER for survival rate (S) and RGR, and GLM for fecundity rate adjusted models, with the proportion of variance explained $\left(R^{2}\right)$ and associated $p$ values

\subsection{Seed rain and seed bank dynamics}

High seed rain and seed bank densities at the beginning of succession indicate no dispersal limitation for the studied pioneer species. Trema and Cecropia produce high numbers of small seeds that are widely dispersed by animals, while Trichospermum produce large crops of small seeds dispersed by wind (Álvarez-Buylla \& MartínezRamos, 1990, 1992; Ibarra-Manríquez et al., 1991). The three species are also abundant in the soil of forest and agricultural sites (LópezToledo \& Martínez-Ramos, 2011). Beyond this similarity, the species exhibited strong differences in seed rain and seed bank dynamics (Figure 2; Figure S5). The sharp decline of Trema's seed rain with fallow age suggests three processes. First, a rapid growth and maturation of the colonizing individuals, and / or a high input of seeds from external sources. Second, a high mortality of reproductive individuals as succession advances (e.g. $>30 \%$ mortality rate after 4 years of succession; Figure $5 \mathrm{~b}$ ). Third, a low arrival of seeds from external sources, once all reproductive individuals have died. In contrast, seed rain of Cecropia and Trichospermum followed a hump-like temporal trajectory. This suggests an increasing number and activity 

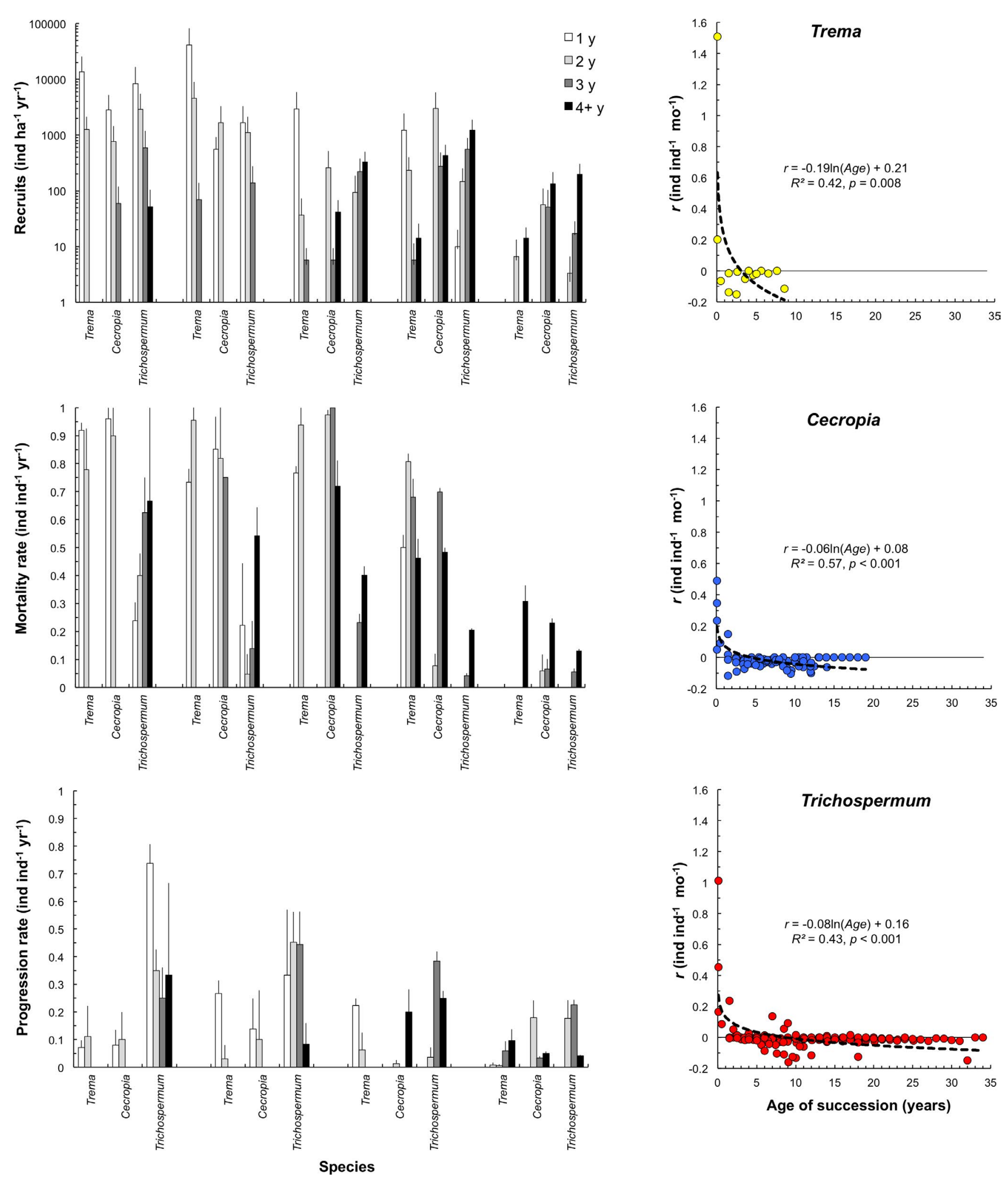

FIGURE 5 Changes of vital rates and intrinsic population growth rate $(r)$ during secondary succession for three pioneer tree species in Marqués de Comillas, Southern Mexico. The (a-c) panels show changes in recruitment, mortality and progression rates for Trema, Cecropia and Trichospermum at the first, second, third and fourth and more years of succession at different life stages (see tags in the top of the first panel). Bars correspond to mean values and vertical lines to one standard error. Panels (d), (e) and (f) show successional trajectories of change of the intrinsic population growth rate $(r)$ for Trema, Cecropia and Trichospermum, respectively; parameters of the best-fitted model (discontinuous curves), the proportion of variance $\left(R^{2}\right)$ explained by the model and its associated significance $p$ level are shown; the horizontal continuous lines indicate demographic equilibrium $(r=0)$ 
of reproductive trees in the first 10-15 years of succession, and a reduction in the reproductive capacity or death of mature trees as they age. Whereas the seed bank for Trema remained similar in density along succession, it increased with fallow age for the other species. The reducing seed rain/seed bank ratio in Trema (Figure S5) is suggestive of a long permanence of their seeds in the soil. For Cecropia, other studies have shown that the seed bank is maintained by the arrival of newly dispersed seeds that compensate for high soil seed predation rates (Álvarez-Buylla \& Martínez-Ramos, 1990; GarcíaOrth \& Martínez-Ramos, 2008). This explains the high seed rain/ seed bank ratio observed in Cecropia along succession (Figure S5). Finally, the low seed rain/seed bank ratio in Trichospermum is indicative of a long residence time of their seeds in the soil (MartínezRamos et al., 2016).

\section{2 | Seedling recruitment}

The temporal window for seedling recruitment after field abandonment was very short and differed among species. For Trema and Cecropia this window was restricted to the first 2 to 3 years, as reported in other studies (Brokaw, 1987; Fleming \& Williams, 1990). Seeds of Cecropia require high red/far-red light ratios to germinate and those of Trema high-temperature fluctuations (Pearson et al., 2002; Válio \& Scarpa, 2001; Vázquez-Yanes \& Smith, 1982). Thus, seedling recruitment in these species is strongly limited once a forest canopy is developed and light radiation and temperature decline in the understorey. In our study plots, the light level was similar to that in the old-growth forest ten years after field abandonment (Matsuo et al., 2021; Ricaño-Rocha, 2007). In contrast, in Trichospermum new seedlings were recorded even after 4 years of fallow age (Figure 5a). The capacity of Trichospermum seeds to germinate in the dark (Sánchez \& Muñoz, 2004) may explain this result.

\subsection{Survival, growth and reproduction rates after recruitment}

The three pioneer species reached a peak in density and biomass and then declined at different rates. The reduction of recruitment of seedlings and juveniles and the high mortality of such individuals were the main determinants of the decline. Shade-intolerance and damages caused by pathogens and herbivores are factors causing mortality in earlier life cycle stages in pioneer trees (Dalling \& Hubbell, 2002). After a density peak in the first year of succession, Trema strongly declined in the absence of new recruits and high mortality rates in juvenile stages (>70\% per year; Figure 5). Cecropia showed a similar trajectory, but their higher recruitment rate than Trema in the premature and mature stages resulted in a density peak after that of Trema (Figure 1). Lower mortality rates and higher recruitment and progression rates exhibited by Trichospermum (Figure 5) after 3 years of field abandonment explain why this species peaks later than the other species.
Our results on size-specific RGR reinforce that Trema is an extreme light-demanding species, Trichospermum a relatively more shade-tolerant one, while Cecropia has an intermediate position. Trema exhibited higher RGR than Cecropia and Trichospermum, especially in small trees ( $\mathrm{DBH}<1 \mathrm{~cm}$; Figure 4), when light availability is high. Other studies have also found that Trema and Cecropia have higher growth rates than Trichospermum (Dalling \& Hubbell, 2002; Dalling et al., 2004). At the population level, however, Trichospermum attained higher biomass than Cecropia and Cecropia higher than Trema during succession (Figure 1b). This was basically due to the highest population density of Trichospermum and the lowest one of Trema.

The studied species also differed in fecundity, indicating they have different life-history strategies. In the context of life-history evolution theory (Silvertown et al., 1999), our pioneer species can be positioned along a spectrum of life histories, between the extremes of high fecundity/low survival (species growing in environments with high resource availability) and low fecundity/high survival (species growing in resource-limited environments). The higher fecundity and lower survival rates of Cecropia, compared to those of Trichospermum (Figure 4), places Cecropia in a more extreme pioneering position than Trichospermum. Although we could not estimate fecundity rates for Trema, the huge seed rain density recorded for this species early in succession (Figure 2 ) is suggestive of a high fecundity. Trema trees become reproductive when reaching 1-6 cm DBH (Silvera et al., 2003). Such tree sizes were common in the young plots and during the years in which the seed rain was surveyed (Figure 3). Thus, we infer that Trema is an extreme pioneer tree species.

\section{4 | Population dynamics}

Population dynamics of Trema correspond to the early colonizing behaviour of a short-lived pioneer species. Trema had the highest population growth rate $(r)$ early in succession and the highest reduction in population growth, with $r<03$ years after field abandonment (Figure 5e). Trema trees grew very fast, attaining maximum size in just 5 years (Figure 4; Figure S4). These results exhibit Trema underwent a severe thinning process along succession. Cecropia experienced a similar process but of lower magnitude, with $r<0$ up until the fourth year of succession and trees growing at a lower rate than Trema. Thinning in Trichospermum was the least severe, with $r>0$ even after 7 years of succession and trees growing at lower rates than Cecropia. These thinning differences resulted in big contrast in population biomass of the species along succession, with Trichospermum attaining, on average, up to 20 times more biomass than Trema, and up to two times more than Cecropia at the peak of maximum biomass (Figure 1b). Also, differences in population dynamics support the idea that tropical pioneer species undergo a regeneration niche partitioning process (sensu Grubb, 1977) along succession (Pearson et al., 2003). Based on our results, we infer that Trema had its regeneration niche requirements met as soon as the 
fields were abandoned, followed closely by Cecropia. These two species, however, were less different from each other and could potentially compete for site colonization, as discussed below.

\subsection{Spatial and temporal variability of successional trajectories}

There was an important spatial variation in the average successional trajectories of change in population density of the studied pioneer species (Figure 1). In some plots, Trema attained a high population density while Cecropia had a very few individuals (Figure S4). In other plots the opposite was true. In most plots, as expected, Trichospermum overcame Cecropia but not always. Such variation indicates that the species replacement process does not necessarily occur in a predictable or regular way. Apparently, some sort of competition occurred between these species, or stochastic factors affected the chance of colonization of the species in different plots (e.g. Norden et al., 2015).

The random effects of plot detected on most demographic variables is indicative that stochasticity, associated with spatial variation in biotic (e.g. competition, herbivory) and abiotic (e.g. soil and topography) factors, played an important role in our successional study system. Differences in agricultural land use (Martínez-Ramos et al., 2016) and land-use history (Jakovac et al., 2021) determine different successional trajectories (Mesquita et al., 2015). Although our plots had the same land use (cornfields) before land abandoned, several differed in land use history (Table S1). For example, plot R-1 underwent a shorter agricultural history than others with the same fallow age (e.g. H-1 and F-1; Table S3). Land-use history determines the site conditions and propagule availability at the moment of abandonment, and hence the colonization opportunities for the different pioneer species (Martínez-Ramos et al., 2016) as shown in Central Amazonia for Vismia and Cecropia species (Mesquita et al., 2015).

Priority effects can also determine different successional trajectories. Trema and Cecropia had more similar regeneration requirements. Therefore, it is possible that an inhibitory priority effect operated on these species. The first species colonizing an open site will inhibit the other species to colonize the same site and vice versa, as suggested by the successional trajectories found in several plots (Figure S4). In our study plots, van Breugel et al. (2012) reported intense competition for light between Cecropia and other pioneer species. Differences among species in factors affecting seed availability, such as seed predation (García-Orth \& Martínez-Ramos, 2008), phenology of seed production within and between years (Fleming \& Williams, 1990; Ibarra-Manríquez et al., 1991), or seed sources in the neighbourhood (Arroyo-Rodríguez et al., 2017), might determine which species colonize firstly a recently opened field. As shown by our results, Trema, Cecropia and Trichospermum have contrasting seed rain and seed bank dynamics, which were influenced by random year effects (see also Grandjean, 2017). This suggests that seed availability for colonization differs between years for these species.
Also, climatic conditions may determine the priority of colonization. It has been shown that recruitment rates during succession varied between years with contrasting levels of rainfall, especially with the amount of rain in the dry season (Martínez-Ramos et al., 2018). Future studies should address the effects of seed sources, environmental conditions and biotic interactions (e.g. competition, seed predation) on the population dynamics of pioneer species. This could help to disentangle priority effects, which apparently occur in a stochastic manner (Norden et al., 2015).

\section{5 | CONCLUSIONS}

On average, the three studied pioneer species were demographically differentiated, exhibiting unsynchronized pathways of change in population density and biomass along succession. However, at the plot level, the species exhibited a strong variability in the successional trajectories, and in some sites, they were mutually exclusive. This produces unpredictability in the sequence of species replacement in a given site. Priority effects, related to the degree of the species shade intolerance, and the site conditions and seed availability at the time of field abandonment, may determine the chance for colonization and the population dynamics followed by each species during succession. The high density, biomass and temporal persistence shown by Trichospermum along succession make this species interesting for ecological restoration. Cecropia, which facilitates the arrival of a wide range of species due to their attractiveness to seed dispersal frugivores, can also be a good candidate for restoration. Trema can be used to develop a forest cover quickly, but only when it is free from light interference from other plants (García-Orth \& Martínez-Ramos, 2011).

\section{ACKNOWLEDGEMENTS}

Research was supported by Semarnat-Conacyt (grants 2002-C010597), SEP-Conacyt (grants CB-2005-01-51043, CB-2009-129740, 179045, 255544), Universidad Autónoma de México DGAPA-PAPIIT (grants IN227210, IN21371, IN211114, IN211417 and IN201020), National Science Foundation (grant DEB-147429), Netherland Organisation for Scientific Research (grant W85-326), and Wageningen University \& Research Interdisciplinary Research and Education Fund (INREF) program (grant FOREFRONT). F Bongers was supported by the European Research Council Advanced Grant PANTROP 834775. This paper constitutes a partial fulfilment of the requirements of the Posgrado en Ciencias Biológicas of the Universidad Nacional Autónoma de México (UNAM) as part of the MSc degree of M.d.M.G.-M. The scholarship (number 825841) of M.d.M.G.-M. was provided by the Consejo Nacional de Ciencia y Tecnología (Conacyt). Special thanks to $M$ van Breugel, J Dupuy, L Markesteijn for sharing some data used in this study, to J RodríguezVelázquez for technical assistance and data management, to $G$ Jamangape and brothers for data collection in the field, and F. Mora Ardila for his technical support on statistics. We thank the two anonymous reviewers and the Associate and Handling editors for their 
excellent and constructive comments. The manuscript was written while M.M.-R. was on a sabbatical.

\section{CONFLICT OF INTEREST}

None of the authors have a conflict of interest.

\section{AUTHORS' CONTRIBUTIONS}

M.M.-R. and M.d.M.G-M. developed the idea and led the writing of the manuscript; M.M.-R., F.B. and M.d.M.G.-M. provided field data; M.M.-R. and M.d.M.G.-M. performed data analysis; F.B., T.V., and E.V. provided comments. All the authors contributed critically to the drafts and gave final approval for publication.

\section{PEER REVIEW}

The peer review history for this article is available at https://publo ns.com/publon/10.1111/1365-2745.13738.

\section{DATA AVAILABILITY STATEMENT}

Data on demography of studied pioneer tree species available from the Dryad Digital Repository https://doi.org/10.5061/dryad.wdbrv 15pd Martínez-Ramos et al. (2021).

\section{ORCID}

Miguel Martínez-Ramos (iD https://orcid. org/0000-0002-7785-1917

María del Mar Gallego-Mahecha iD https://orcid.

org/0000-0003-3410-2323

Ernesto Vega (iD https://orcid.org/0000-0003-1258-814X

Frans Bongers iD https://orcid.org/0000-0002-8431-6189

\section{REFERENCES}

Aide, T. M., Clark, M. L., Grau, H. R., López-Carr, D., Levy, M. A., Redo, D., Bonilla-Moheno, M., Riner, G., Andrade-Núñez, M. J., \& Muñiz, M. (2013). Deforestation and reforestation of Latin America and the Caribbean (2001-2010). Biotropica, 45, 262-271. https://doi. org/10.1111/j.1744-7429.2012.00908.x

Álvarez-Buylla, E., \& Martínez-Ramos, M. (1990). Seed bank versus seed rain in the regeneration of a tropical pioneer tree. Oecologia, 84, 314325. https://doi.org/10.1007/BF00329755

Álvarez-Buylla, E., \& Martínez-Ramos, M. (1992). Demography and allometry of Cecropia obtusifolia, a neotropical pioneer tree - An evaluation of the climax-pioneer paradigm for tropical rain forests. Journal of Ecology, 80, 275-290. https://doi.org/10.2307/2261011

Anderson, D. (2008). Model based inference in the life sciences: A primer on evidence. Springer.

Arroyo-Rodríguez, V., Melo, F. P. L., Martínez-Ramos, M., Bongers, F., Chazdon, R. L., Meave, J. A., Norden, N., Santos, B. A., Leal, I. R., \& Tabarelli, M. (2017). Multiple successional pathways in humanmodified tropical landscapes: New insights from forest succession, forest fragmentation and landscape ecology research. Biological Reviews, 92, 326-340. https://doi.org/10.1111/brv.12231

Bates, D., Maechler, M., Bolker, B., \& Walker, S. (2015). Fitting linear mixedeffects models using Ime4. Journal of Statistical Software, 67, 1-48.

Bongers, F., \& Popma, J. (1990). Leaf characteristics of the tropical rain forest flora of Los Tuxtlas, Mexico. Botanical Gazette, 151, 354-365. https://doi.org/10.1086/337836
Brancalion, P., \& van Mellis, J. (2017). On the need for innovation in ecological restoration. Annals of the Missouri Botanical Garden, 102, 227236. https://doi.org/10.3417/2016034

Brokaw, N. V. (1987). Gap-phase regeneration of three pioneer tree species in a tropical forest. Journal of Ecology, 75, 9. https://doi. org/10.2307/2260533

Brown, S., \& Lugo, A. E. (1990). Tropical secondary forests. Journal of Tropical Ecology, 6, 1-32. https://doi.org/10.1017/S026646740 0003989

Carabias, J., de la Maza, J., \& Cadena, R. (2015). Conservación y desarrollo sustentable en la Selva Lacandona. 25 años de actividades y experiencias. Natura y Ecosistemas Mexicanos, A.C. Redacta S.A. de C.V. México.

Chazdon, R. L. (2014). Second growth: The promise of tropical forest regeneration in an age of deforestation. The University of Chicago Press.

Chazdon, R. L., Broadbent, E. N., Rozendaal, D. M. A., Bongers, F., Zambrano, A. M. A., Aide, T. M., Balvanera, P., Becknell, J. M., Boukili, V., Brancalion, P. H. S., Craven, D., Almeida-Cortez, J. S., Cabral, G. A. L., de Jong, B., Denslow, J. S., Dent, D. H., DeWalt, S. J., Dupuy, J. M., Durán, S. M., ... Poorter, L. (2016). Carbon sequestration potential of second-growth forest regeneration in the Latin American tropics. Science Advances, 2(5), e1501639. https://doi.org/10.1126/ sciadv.1501639

Connell, J. H., \& Slatyer, R. (1977). Mechanisms of succession in natural communities and their role in community stability and organization. American Society of Naturalists, 111, 1119-1144. https://doi. org/10.1086/283241

Dalling, J. W., \& Hubbell, S. P. (2002). Seed size, growth rate and gap microsite conditions as determinants of recruitment success for pioneer species. Journal of Ecology, 90, 557-568. https://doi. org/10.1046/j.1365-2745.2002.00695.x

Dalling, J. W., Winter, K., \& Hubbell, S. P. (2004). Variation in growth responses of neotropical pioneers to simulated forest gaps. Functional Ecology, 18, 725-736. https://doi. org/10.1111/j.0269-8463.2004.00868.x

Estrada, A., Coates-Estrada, R., \& Vázquez-Yanes, C. (2010). Observations on fruiting and dispersers of Cecropia obtusifolia at Los Tuxtlas, Mexico. Biotropica, 16, 315-318. https://doi.org/10.2307/2387942

Finegan, B. (1984). Forest succession. Nature, 312, 109-114. https://doi. org/10.1038/312109a0

Fleming, T., \& Williams, C. F. (1990). Phenology, seed dispersal, and recruitment in Cecropia peltata (Moraceae) in Costa Rican tropical dry forest. Journal of Tropical Ecology, 6, 163-178.

Fukami, T. (2015). Historical contingency in community assembly: Integrating niches, species pools, and priority effects. Annual Review of Ecology, Evolution, and Systematics, 46, 1-23. https://doi. org/10.1146/annurev-ecolsys-110411-160340

García-Orth, X., \& Martínez-Ramos, M. (2008). Seed dynamics of early and late successional tree species in tropical abandoned pastures: Seed burial as a way of evading predation. Restoration Ecology, 16, 435-443. https://doi.org/10.1111/j.1526-100X.2007.00320.x

García-Orth, X., \& Martínez-Ramos, M. (2011). Isolated trees and grass removal improve performance of transplanted Trema micrantha (L.) Blume (Ulmaceae) saplings in tropical pastures. Restoration Ecology, 19, 24-34. https://doi.org/10.1111/j.1526-100X.2009.00536.x

Gómez-Pompa, A., Vásquez-Yanes, C., \& Guevara, S. (1972). The tropical rain forest: A non-renewable resource. Science, 117, 762-765. https://doi.org/10.1126/science.177.4051.762

Grandjean, T. (2017). Seed rain during succession in a wet lowland neotropical forest (MSc thesis). Wageningen University \& Research.

Grubb, P. J. (1977). The Maintenance of species-richness in plant communities: The importance of the regeneration niche. Biological Reviews, 52, 107-145. https://doi.org/10.1111/j.1469-185X.1977.tb01347.x 
Halpern, C. B. (1989). Early successional patterns of forest species: Interactions of life history traits and disturbance. Ecology, 70, 704720. https://doi.org/10.2307/1940221

Hansen, M. C., Potapov, P. V., Moore, R., Hancher, M., Turubanova, S. A., Tyukavina, A., Thau, D., Stehman, S. V., Goetz, S. J., Loveland, T. R., Kommareddy, A., Egorov, A., Chini, L., Justice, C. O., \& Townshend, J. R. G. (2013). High-Resolution global maps of 21st-century forest cover change. Science, 850, 2011-2014. https://doi.org/10.1126/ science.1244693

Horn, H. S. (1974). The ecology of secondary succession. Annual Review of Ecology and Systematics, 5, 25-37. https://doi.org/10.1146/annur ev.es.05.110174.000325

Hubbell, S. P. (2005). Neutral theory in community ecology and the hypothesis of functional equivalence. Functional Ecology, 19, 166-172. https://doi.org/10.1111/j.0269-8463.2005.00965.x

Huston, M., \& Smith, T. (1987). Plant succession: Life history and competition. The American Naturalist, 130, 168-198. https://doi. org/10.1086/284704

Ibarra-Manríquez, G., Sánchez-Garfias, B., \& González-García, L. (1991). Fenología de lianas y árboles anemócoros en una selva cálido húmeda en México. Biotropica, 23, 242-254.

Jakovac, C. C., Junqueira, A. B., Crouzeilles, R., Peña-Claros, M., Mesquita, R. C. G., \& Bongers, F. (2021). The role of land-use history in driving successional pathways and its implications for the restoration of tropical forests. Biological Reviews. https://doi.org/10.1111/ brv.12694

Lohbeck, M., Poorter, L., Martínez-Ramos, M., \& Bongers, F. (2015). Biomass is the main driver of changes in ecosystem process rates during tropical forest succession. Ecology, 96, 1242-1252. https:// doi.org/10.1890/14-0472.1

López-Toledo, L., \& Martínez-Ramos, M. (2011). The soil seed bank in abandoned tropical pastures: Source of regeneration or invasion? Revista Mexicana de Biodiversidad, 82, 663-678. https://doi. org/10.22201/ib.20078706e.2011.2.462

Marcante, S., Winkler, E., \& Erschbamer, B. (2009). Population dynamics along a primary succession gradient: Do alpine species fit into demographic succession theory? Annals of Botany, 103, 1129-1143. https://doi.org/10.1093/aob/mcp047

Martínez-Ramos, M. (1985). Claros, ciclos vitales de los árboles tropicales y regeneración natural de las selvas altas perennifolias. In A. GómezPompa \& S. del Amo (Eds.), Investigaciones sobre la regeneración de selvas altas en Veracruz, México (pp. 191-239). INIREB, Alhambra Editorial.

Martínez-Ramos, M., Álvarez-Buylla, E., \& Sarukhán, J. (1989). Tree demography and gap dynamics in a tropical rainforest. Ecology, 70, 555558. https://doi.org/10.2307/1940203

Martínez-Ramos, M., Anten, N. P., \& Ackerly, D. D. (2009). Defoliation and ENSO effects on vital rates of an understorey tropical rain forest palm. Journal of Ecology, 3, 1050-1061. https://doi. org/10.1111/j.1365-2745.2009.01531.x

Martínez-Ramos, M., Balvanera, P., Arreola, L. F., Mora, F., Maass, M., \& Maza-Villalobos, S. (2018). Effects of long-term inter-annual rainfall variation on the dynamics of regenerative communities during the old-field succession of a Neotropical dry forest. Forest Ecology and Management, 426, 91-100. https://doi.org/10.1016/j. foreco.2018.04.048

Martínez-Ramos, M., del Mar Gallego-Mahecha, M., Valverde, T., Vega, E., \& Bongers, F. (2021). Data from: Demographic differentiation among pioneer tree species during old-field succession of a Neotropical rainforest. Dryad Digital Repository, https://doi.org/10.5061/dryad.wdbrv15pd

Martínez-Ramos, M., Pingarroni, A., Rodríguez-Velázquez, J., ToledoChelala, L., Zermeño-Hernández, I., \& Bongers, F. (2016). Natural forest regeneration and ecological restoration in human-modified tropical landscapes. Biotropica, 48, 745-757. https://doi.org/10.1111/ btp.12382
Matsuo, T., Martínez-Ramos, M., Bongers, F., van der Sande, M. T., \& Poorter, L. (2021). Forest structure drives changes in light heterogeneity during tropical secondary forest succession. Journal of Ecology. https://doi.org/10.1111/1365-2745.13680

Mesquita, R. C. G., dos Santos Massoca, P. E., Jakovac, C. C., Vizcarra Bentos, T., \& Williamson, G. B. (2015). Amazon rain forest succession: Stochasticity or land-use legacy? BioScience, 65, 849-861. https:// doi.org/10.1093/biosci/biv108

Metcalf, J. C. E., Horvitz, C. C., Tuljapurkar, S., \& Clark, D. A. (2009). A time to grow and a time to die: A new way to analyse the dynamics of size, light, age, and death of tropical trees. Ecology, 90, 2766-2778.

Navarrete-Segueda, A., Martínez-Ramos, M., Ibarra-Manríquez, G., Cortés-Flores, J., Vázquez-Selem, L., \& Siebe, C. (2017). Availability and species diversity of forest products in a Neotropical rainforest landscape. Forest Ecology and Management, 406, 242-250. https:// doi.org/10.1016/j.foreco.2017.08.037

Norden, N., Angarita, H. A., Bongers, F., Martínez-Ramos, M., Granzow-de la Cerda, I., van Breugel, M., Lebrija-Trejos, E., Meave, J. A., Vandermeer, J., Williamson, G. B., Finegan, B., Mesquita, R., \& Chazdon, R. L. (2015). Successional dynamics in neotropical forests are as uncertain as they are predictable. Proceedings of the National Academy of Sciences of the United States of America, 112, 8013-8018. https://doi.org/10.1073/pnas.1500403112

Otárola, M. F., \& Avalos, G. (2014). Demographic variation across successional stages and their effects on the population dynamics of the neotropical palm Euterpe precatoria. American Journal of Botany, 101, 1023-1028.

Pascarella, J. B., Aide, T. M., \& Zimmerman, J. K. (2007). The demography of Miconia prasina (Melastomataceae) during secondary succession in Puerto Rico. Biotropica, 39, 54-61. https://doi. org/10.1111/j.1744-7429.2006.00220.x

Pearson, T., Burslem, D. F., Goeriz, R. E., \& Dalling, J. W. (2003). Regeneration niche partitioning in neotropical pioneers: Effects of gap size, seasonal drought and herbivory on growth and survival. Oecologia, 137, 456-465. https://doi.org/10.1007/s0044 2-003-1361-x

Pearson, T., Burslem, D. F., Mullins, C. E., \& Dalling, J. W. (2002). Germination ecology of neotropical pioneers: Interacting effects of environmental conditions and seed size. Ecology, 83, 2798-2807.

Pennington, T. D., \& Sarukhán, J. (2005). Árboles tropicales de México. Manual para la identificación de las principales especies (3ra. edición). Fondo de Cultura Económica.

Pinheiro, J., Bates, D., DebRoy, S., Sarkar, D., \& R Core Team. (2020). nlme: Linear and nonlinear mixed effects models. $\mathrm{R}$ package version 3.1-145. Retrieved from https://CRAN.R-project.org/package=nlme

Poorter, L., Bongers, F., Aide, T. M., Zambrano, A. M. A., Balvanera, P., Becknell, J. M., Boukili, V., Brancalion, P. H., Broadbent, E. N., Chazdon, R. L., \& Craven, D. (2016). Biomass resilience of Neotropical secondary forest. Nature, 530, 211-214.

Poorter, L., Wright, S. J., Paz, H., Ackerly, D., Condit, R., Ibarra-Manríquez, G., Harms, K. E., Licona, J. C., Martínez-Ramos, M., Mazer, S. J., Muller-Landau, H., Peña-Claros, M., Webb, C. O., \& Wright, I. J. (2008). Are functional traits good predictors of demographic rates? Evidence from five Neotropical forest. Ecology, 89, 1908-1920.

Primack, R. B., \& Lee, H. S. (1991). Population dynamics of pioneer (Macaranga) trees and understorey (Mallotus) trees (Euphorbiaceae) in primary and selectively logged Bornean rain forests. Journal of Tropical Ecology, 7, 439-457.

R Core and Team. (2020). R: A language and environment for statistical computing. R Foundation for Statistical Computing. Retrieved from http://www.r-project.org/index.html

Ricaño-Rocha, A. (2007). Morfología aérea de plántulas tropicales: variación a lo largo del gradiente sucesional en campos abandonados en una selva alta (MSc thesis). Universidad Nacional Autónoma de México. 
Rodríguez-Velázquez, J., Sinaca-Colín, P., \& Jamangapé-García, G. (2009). Frutos y semillas de árboles tropicales de México. Retrieved from http:// scholar.google.com/scholar?hl=en\&btnG=Search\&q=intitle:No+Title\#2

Rozendaal, D. M. A., Bongers, F., Aide, T. M., Alvarez-Dávila, E., Ascarrunz, N., Balvanera, P., Becknell, J. M., Bentos, T. V., Brancalion, P. H. S., Cabral, G. A. L., Calvo-Rodriguez, S., Chave, J., César, R. G., Chazdon, R. L., Condit, R., Dallinga, J. S., de Almeida-Cortez, J. S., de Jong, B., de Oliveira, A., ... Poorter, L. (2019). Biodiversity resilience of Neotropical secondary forests. Science Advances, 5, 1-10. https:// doi.org/10.1126/sciadv.aau3114

Sanchez, E., Gallery, R., \& Dalling, J. (2009). Importance of nurse logs as a substrate for the regeneration of pioneer tree species on Barro Colorado Island, Panama. Journal of Tropical Ecology, 25, 429-437. https://doi.org/10.1017/S0266467409006130

Sánchez, J. A., \& Muñoz, B. C. (2004). Effects of hydration and scarification treatments on the germination of Trichospermum mexicanum. Seed Science and Technology, 32, 621-627. https://doi.org/10.15258/ sst.2004.32.2.31

Santos, G. G., Santos, B. A., Nascimento, H. E. M., \& Tabarelli, M. (2012). Contrasting demographic structure of short- and long-lived pioneer tree species on Amazonian forest edges. Biotropica, 44, 771-778. https://doi.org/10.1111/j.1744-7429.2012.00882.x

Silvera, K., Skillman, J., \& Dalling, J. (2003). Seed germination, seedling growth and habitat partitioning in two morphotypes of the tropical pioneer tree Trema micrantha in a seasonal forest in Panama. Journal of Tropical Ecology, 19, 27-34.

Silvertown, J., \& Franco, M. (1993). Plant demography and habitat: A comparative approach. Plant Species Biology, 8, 67-73. https://doi. org/10.1111/j.1442-1984.1993.tb00058.x

Silvertown, J., Franco, M., \& Harper, J. L. (1999). Plant life histories: Ecology, phylogeny, and evolution. Cambridge University Press.

Suazo-Ortuño, I., Lopez-Toledo, L., Alvarado-Díaz, J., \& Martínez-Ramos, M. (2015). Land-use change dynamics, soil type and species forming mono-dominant patches: The case of Pteridium aquilinum in a neotropical rain forest region. Biotropica, 47, 18-26.

Swaine, M. D., \& Whitmore, T. C. (1988). On the definition of ecological species groups in tropical rain forests. Vegetatio, 75, 81-86. https:// doi.org/10.1007/BF00044629

Turubanova, S., Potapov, P. V., Tyukavina, A., \& Hansen, M. C. (2018). Ongoing primary forest loss in Brazil, Democratic Republic of the Congo, and Indonesia. Environmental Research Letters, 13. https://doi. org/10.1088/1748-9326/aacd1c

Válio, I. F. M., \& Scarpa, F. M. (2001). Germination of seeds of tropical pioneer species under controlled and natural conditions. Revista
Brasileira de Botânica, 24, 79-84. https://doi.org/10.1590/S0100 $-84042001000100009$

Valverde, T., \& Silvertown, J. (1998). Variation in the demography of a woodland understorey herb (Primula vulgaris) along the forest regeneration cycle: Projection matrix analysis. Journal of Ecology, 86, 545-562.

van Breugel, M., Bongers, F., \& Martínez-Ramos, M. (2007). Species dynamics during early secondary forest succession: Recruitment, mortality and species turnover. Biotropica, 39, 610-619. https://doi. org/10.1111/j.1744-7429.2007.00316.x

van Breugel, M., Martínez-Ramos, M., \& Bongers, F. (2006). Community dynamics during early secondary succession in Mexican tropical rain forests. Journal of Tropical Ecology, 22, 663-674. https://doi. org/10.1017/S0266467406003452

van Breugel, M., Ransijn, J., Craven, D., Bongers, F., \& Hall, J. S. (2011). Estimating carbon stock in secondary forests: Decisions and uncertainties associated with allometric biomass models. Forest Ecology and Management, 262, 1648-1657. https://doi.org/10.1016/j. foreco.2011.07.018

van Breugel, M., van Breugel, P., Jansen, P. A., Martínez-Ramos, M., \& Bongers, F. (2012). The relative importance of above-versus belowground competition for tree growth during early succession of a tropical moist forest. Plant Ecology, 213, 25-34. https://doi.org/10.1007/ s11258-011-0003-3

Vázquez-Yanes, C., \& Smith, H. (1982). Phytochrome control of seed germination in the tropical rainforest pioneer trees Cecropia obtusifolia and Piper auritum and its ecological significance. New Phytologist, 92, 477-485. https://doi.org/10.1111/ j.1469-8137.1982.tb03405.x

\section{SUPPORTING INFORMATION}

Additional supporting information may be found online in the Supporting Information section.

How to cite this article: Martínez-Ramos, M., GallegoMahecha, M. M., Valverde, T., Vega, E., \& Bongers, F. (2021). Demographic differentiation among pioneer tree species during secondary succession of a Neotropical rainforest. Journal of Ecology, 00, 1-15. https://doi.org/10.1111/1365-2745.13738 